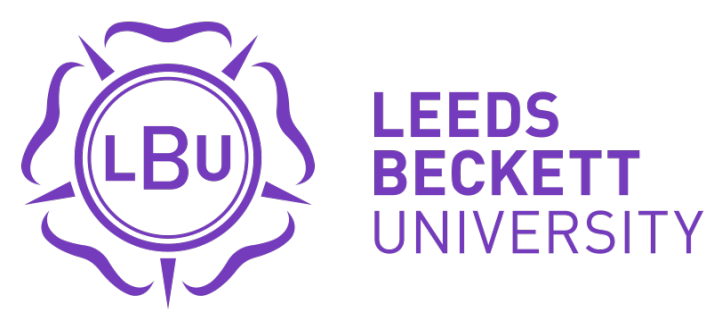

Citation:

Taleghani, M and Swan, W and Johansson, E and Ji, Y (2020) Urban cooling: which façade orientation has the most impact on a microclimate? Sustainable Cities and Society. p. 102547. ISSN 2210-6707 DOI: https://doi.org/10.1016/j.scs.2020.102547

Link to Leeds Beckett Repository record:

https://eprints.leedsbeckett.ac.uk/id/eprint/7161/

Document Version:

Article (Accepted Version)

This is an Accepted Manuscript of an article published by Elsevier in Sustainable Cities and Society on 15th October 2020, available online: https://doi.org/10.1016/j.scs.2020.102547

The aim of the Leeds Beckett Repository is to provide open access to our research, as required by funder policies and permitted by publishers and copyright law.

The Leeds Beckett repository holds a wide range of publications, each of which has been checked for copyright and the relevant embargo period has been applied by the Research Services team.

We operate on a standard take-down policy. If you are the author or publisher of an output and you would like it removed from the repository, please contact us and we will investigate on a case-by-case basis.

Each thesis in the repository has been cleared where necessary by the author for third party copyright. If you would like a thesis to be removed from the repository or believe there is an issue with copyright, please contact us on openaccess@leedsbeckett.ac.uk and we will investigate on a case-by-case basis. 


\title{
Urban cooling: which façade orientation has the most impact on a microclimate?
}

\author{
Mohammad Taleghani ${ }^{1^{*}}$, William Swan ${ }^{2}$, Erik Johansson ${ }^{3}$, Yingchun $\mathrm{Ji}^{2}$ \\ ${ }^{1}$ Leeds Beckett University, Leeds, UK \\ ${ }^{2}$ University of Salford, Manchester, UK \\ ${ }^{3}$ Lund University, Lund, Sweden \\ ${ }^{1}$ Corresponding author: \\ Mohammad Taleghani (m.taleghani@leedsbeckett.ac.uk)
}

\section{Highlights:}

- High albedo materials were implemented on facades with different orientations;

- Façade insolation, ground surface temperature, and surface energy balance were reported;

- EW canyon receives 6 hours of direct sun more than the NS canyon;

- East and west cool facades led to the maximum net radiation reductions;

- North and south facades had negligible contributions in reducing PET.

\section{Abstract}

Deploying solar reflective materials on urban surfaces is known as an effective heat mitigation strategy. Several studies have shown their cooling impacts; however, most of them have focused on rooftops rather than facades. The novelty of this paper is related to 
exploring the impact of each façade orientation on the corresponding microclimate and energy balance. High albedo materials were implemented on facades with different orientations to explore the potential of each façade. Computer simulations were employed to calculate the insolation of different façades, ground surface temperature, and surface energy balances. The simulations are done for the longest day of the year $\left(21^{\text {st }}\right.$ of June) to have the maximum solar radiation on all facades. The results showed that east-west canyons receive 6 hours more direct sun than north-south canyons. This proved that eastern and western facades have the most impact on the microclimate. Cooling east and west facades led to the maximum net radiation reductions for the ground surface. Furthermore, north and south facades had negligible contributions to pedestrian thermal comfort. By understanding the role of each façade, designers and policy makers could deploy cooling materials more effectively on building surfaces.

\section{Keywords}

Cool walls, façade orientation, insolation, energy balance, thermal comfort

\section{Introduction}

Dark surfaces covering urban spaces increase the urban heat island effect (Oke et al., 2017, Taha, 2013, Arnfield, 2003). Deploying solar reflective (or cool) materials on urban surfaces is known as an effective heat mitigation strategy. Reflective materials with higher albedo (solar reflectivity) and higher emittance of longwave radiation can reflect a higher portion of received solar radiation back to the atmosphere (EPA, 2008). This would lead to less solar absorption (compared to using conventional materials like asphalt and concrete with low albedo). Several cities in south Europe and north Africa are covered with white colour or plaster (e.g. Santorini in Greece, Almeria in Spain). Reducing urban temperatures in hot summers improves citizens' health and comfort (Santamouris, 2014, Taleghani et al., 2019b, Sailor et al., 2019, Ahmadi Venhari et al., 2019, Santamouris, 2015), air quality (Taha, 2015, Taha, 2008), and energy use (Akbari and Kolokotsa, 2016, Erell et al., 2012, Levinson, 2019, Santamouris et al., 2018).

The cooling impact of reflective materials has been studied from the global scale to a single element of a building (i.e. a rooftop):

In a global scale, Akbari and Matthews (2012) studied the impact of increasing urban albedo by 0.1 in cities between $45^{\circ} \mathrm{N}$ and $45^{\circ} \mathrm{S}$. They showed that increasing the albedo will cool these urban areas, and consequently reduces the $\mathrm{CO}_{2}$ emissions by $80 \mathrm{Gt}$ in the first 50 years of deployment by reducing the need for energy use in space conditioned buildings. This also improves indoor thermal comfort in free running buildings in summer time.

In a regional scale study, Mohegh et al. (2017) quantified the impact of increasing urban pavement albedos by 0.4 in Californian cities. They showed that annual average air temperatures at $2 \mathrm{~m}$ height were reduced between 0.18 to $0.86{ }^{\circ} \mathrm{C}$ in different cities. They observed that maximum air temperature reductions occur in the late morning and early evenings, when the boundary layer heights are low.

In an urban scale project, Santamouris et al. (2012) investigated the cooling impact of adopting $4500 \mathrm{~m}^{2}$ of "cool pavements" within a park in Athens, Greece. This project led to 
the reduction of air and surface temperatures by 1.9 and $12 \mathrm{~K}$, respectively. As a result, higher pedestrian thermal comfort was achieved in the park in summer days.

In a building scale study, Baniassadi et al. (2018) modelled a cool roof for residential buildings in different cities within the Los Angeles Basin (in a free running mode). They showed that deployment of cool surfaces has direct (building indoor environment) and indirect (neighbourhood outdoor environment) benefits. They observed that cool materials improve the indoor environment of poorly insulated buildings more than high performance buildings. They found out that by increasing the albedo from 0.2 to 0.5 , energy use and indoor thermal comfort were improved by $41 \%$ (poorly insulated buildings) and $23 \%$ (high performance buildings) in Long Beach (CA), respectively.

The novelty of this paper is related to exploring the impact of each façade orientation on the corresponding microclimate and energy balance. Several studies have shown the cooling impact of reflective rooftops; however, there are few studies addressing reflective/cool walls. This might be due to the fact that the sun radiates the rooftops more than other building facades at noon in summertime. However, vertical facades receive direct sun for a longer period in summer (compared to roofs). This indicates the potential of different facades in contributing to the local heat islands.

In this paper, we want to explore the potential of different façade orientations on cooling a microclimate. This will be explored through computer modelling of insolation on different facades, micrometeorological simulation using a computational fluid dynamic model, and the human thermal comfort calculations. We will design a hypothetical neighbourhood with identical buildings. To evaluate the impact of solar reflective facades, a sunny city was required. We chose Los Angeles in Southern California (latitude $33.9^{\circ} \mathrm{N}$ ) which is a good example of a city experiencing high rates of urban heat islands (Taha, 2017, Taleghani et al., 2019a, Zhang et al., 2018), and covered with dark surfaces (Akbari et al., 2008). Reflective materials will be added to all the facades facing north, east, south and west (each in a separate scenario). Solar radiation and human thermal comfort will be assessed in each scenario to explore cooling and which façade contributes more to reducing heat stress in a microclimate. By understanding the role of each façade, designers and policy makers could deploy cooling materials more effectively on building surfaces.

Regarding the structure of the paper, first we explain the methodology of the research (i.e. insolation modelling, the ENVI-met model, and outdoor thermal comfort calculation); then in the results, we present the validation part on the Control simulation scenario, the insolation received by different facades, and at the end we will show how increasing the albedo of each façade will contribute to the microclimate and ground surface energy balance.

\section{Methodology}

To understand the role of each façade in mitigating/contributing the heat in a microclimate, a hypothetical neighbourhood was designed. The neighbourhood was designed in a way that we could increase the albedo of different facades, and to report the surface energy balance, surface temperature and thermal comfort in the neighbourhood. Figure 1 shows the size of the domain area, and the buildings within it. The neighbourhood is $100 \mathrm{~m} \times 100 \mathrm{~m}$, with 16 identical buildings located in a grid structure similar to residential areas in Los Angeles. The height, width and length of the buildings are $10 \mathrm{~m} \times 10 \mathrm{~m} \times 10 \mathrm{~m}$, respectively (assuming typical three storey detached houses). 


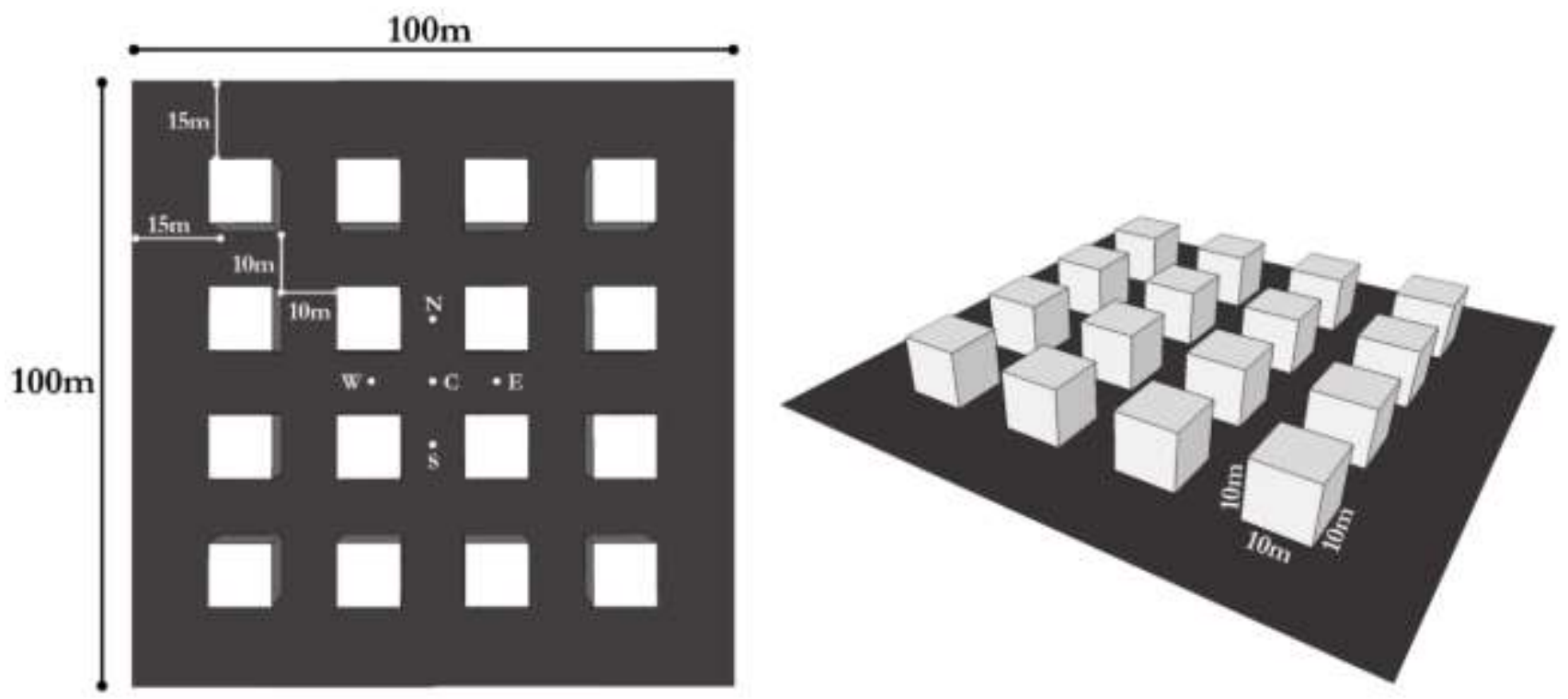

Figure 1: The plan of the simulation domain, illustrating the dimensions and the receptors (left); the 3D model of the domain (right).

Regarding the weather data, Typical Meteorological Year (TMY3) data for Los Angeles International Airport (LAX) was available from the EnergyPlus weather data library (EnergyPlus, 2018). Los Angeles has hot summers with a Mediterranean climate, with the mean annual temperature of $18.2^{\circ} \mathrm{C}$ (Csa in Köppen-Geiger classification (Kottek et al., 2006)). In this study, we used data on the $21^{\text {st }}$ of June for our simulations as it is the longest day of the year. The prevailing wind direction in Los Angeles basin is from west (Figure 2). 
a)

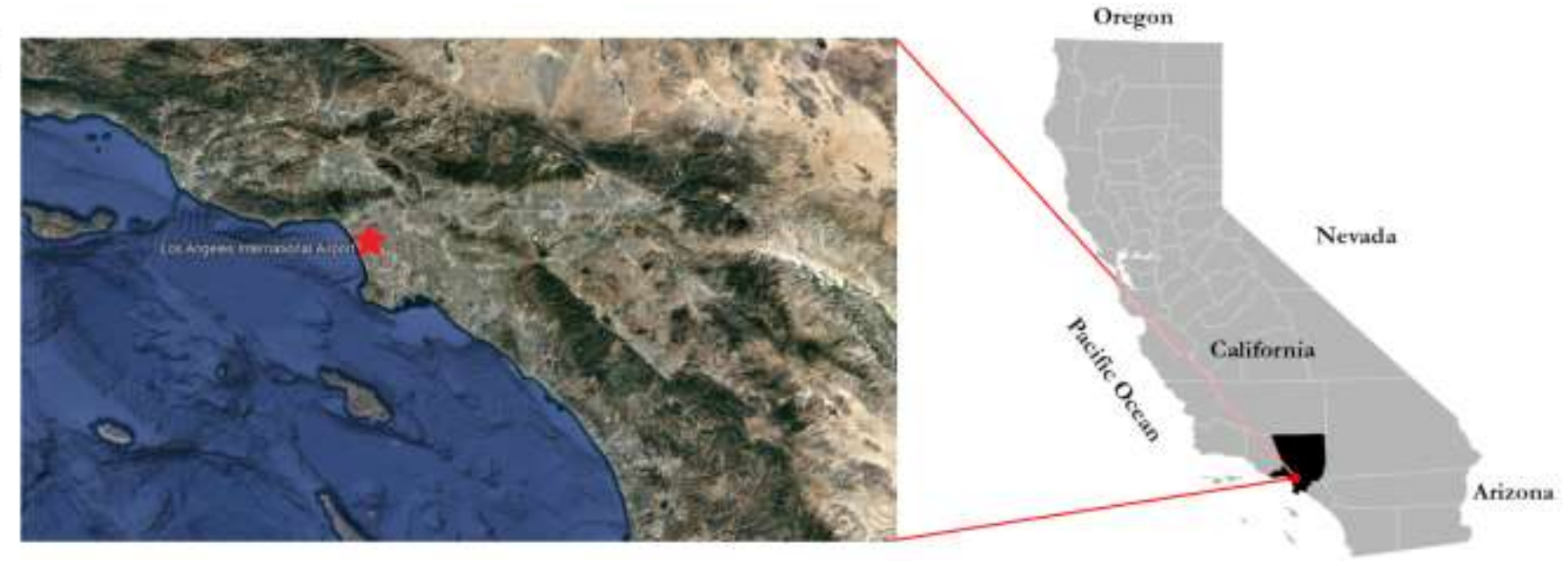

b)

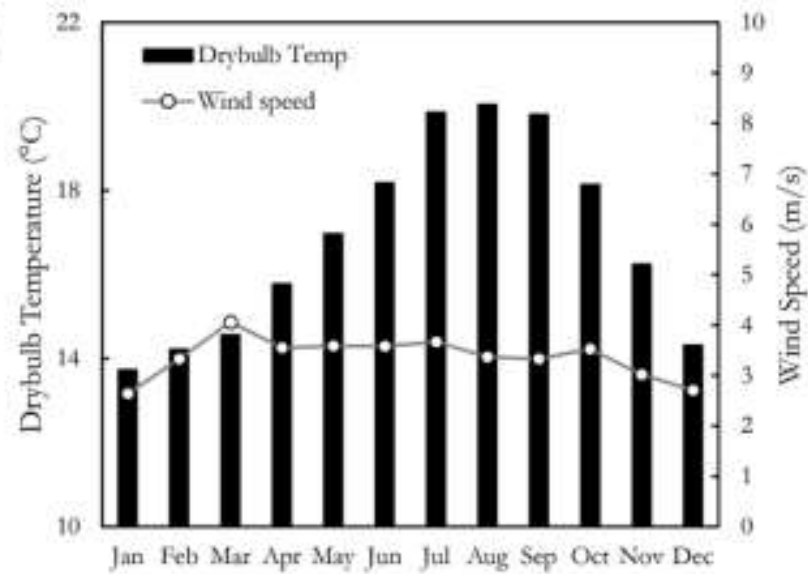

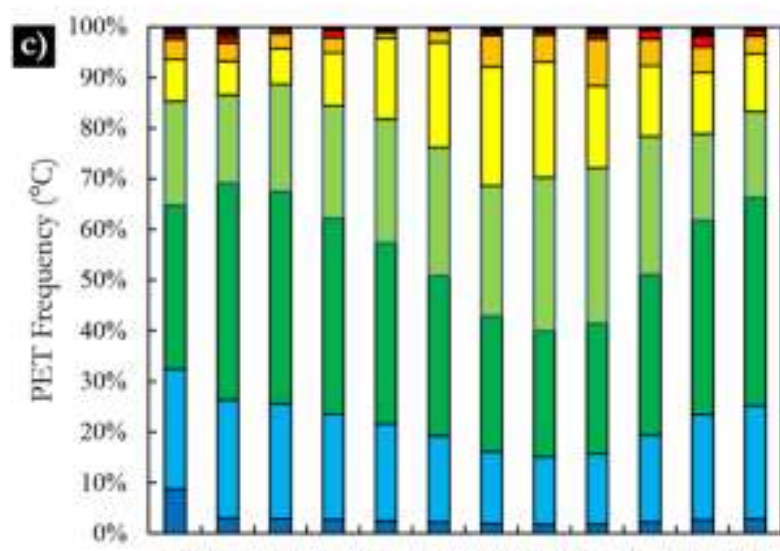

Jan Feb Mar Apt May Jun Jul Aug Sep Oct Nov Dec
- Very hot

eHot

nWarm

口Slightly wam

口Comfortable

aSlightly cool

aCool

ecold

e Very cold

Figure 2: a) The location of Los Angeles International Airport (LAX) in the west side of Los Angeles Basin in Southern California. b) The average monthly ambient air temperature and wind speed in LAX. c) The monthly outdoor thermal comfort expressed in PET.

We followed three steps to find the most effective façade(s):

\subsection{Insolation modelling}

We modelled the neighbourhood in Sketchup 2018. Chronolux 1.2 as a plugin for Sketchup allows to calculate the duration of insolation (the amount of solar radiation received by a given area) of different facades for a specific date and coordination. We calculated the insolation duration of different facades for one of the buildings shown in Figure 1 (for the coordinates of Los Angeles airport on the $21^{\text {st }}$ of June).

\subsection{Microclimate modelling}

To calculate the microclimatic parameters of the neighbourhood, we used ENVI-met 4.3 (Bruse, 2020). This software is widely used for neighbourhood scale modelling with a high spatial resolution (0.5 to $10 \mathrm{~m}$ ). ENVI-met has four main components: atmosphere, buildings, vegetation and soil (Bruse, 2004). To resolve the turbulent flows, ENVI-met uses the nonhydrostatic incompressible Navier-Stokes equations (Bruse and Fleer, 1998): 
$\frac{\partial u}{\partial t}+u_{i} \frac{\partial u}{\partial x_{i}}=-\frac{\partial p^{\prime}}{\partial x}+K_{m}\left(\frac{\partial^{2} u}{\partial x_{i}^{2}}\right)+f\left(v-v_{g}\right)-S_{u}$

$\frac{\partial v}{\partial t}+u_{i} \frac{\partial v}{\partial x_{i}}=-\frac{\partial p^{\prime}}{\partial y}+K_{m}\left(\frac{\partial^{2} v}{\partial x_{i}^{2}}\right)-f\left(u-u_{g}\right)-S_{v}$

$\frac{\partial w}{\partial t}+u_{i} \frac{\partial w}{\partial x_{i}}=-\frac{\partial p^{\prime}}{\partial z}+K_{m}\left(\frac{\partial^{2} w}{\partial x_{i}^{2}}\right)+g \frac{\Theta(z)}{\theta_{r e f}(z)}-S_{w}$

$\frac{\partial u}{\partial x}+\frac{\partial v}{\partial y}+\frac{\partial w}{\partial z}=0$

where, wind in $\mathrm{x}, \mathrm{y}$ and $\mathrm{z}$ directions are shown with $\mathrm{u}, \mathrm{v}$ and $\mathrm{w} ; p^{\prime}$ is the local pressure perturbation; geostrophic wind directions are also shown with $v_{g}$ and $u_{g} ; K_{m}$ will be the momentum diffusivity of air; $f$ is the Coriolis coefficient; $S_{u}, S_{v}$ and $S_{w}$ are loss of wind speed in different directions due to drag forces at vegetation; potential temperature is shown by $\theta$ (at height of $z$ ); $\theta_{\text {ref }}(z)$ is the reference temperature (at height of $z$ ); and finally gravity is shown by $g$. For all 3D advection and diffusion terms $u_{i}=u, v, w$. For mean wind speed, temperature and humidity calculations see Bruse (2004).

To run the simulations, ENVI-met uses 2-equation Turbulence Kinetic Energy (TKE) Model to estimate the turbulence. The first equation solves the distribution of the kinetic energy in the air, and the second one describes the dissipation rate of TKE $(\varepsilon)$. For the equations, see (Bruse, 2019). The time steps of the simulations were 1 hour.

The physical domain of the neighbourhood in ENVI-met was modelled based on Figure 1. Regarding the surface properties within the domain:

- $\quad$ the ground surface is covered with asphalt (albedo 0.2),

- the building facades with brick (albedo 0.4), and

- the rooftops with tiles (albedo 0.5).

We called this model as our Control scenario.

We also designed five perturbation scenarios to test the impact of high albedo materials on different facades. In four of them, we increased the albedo of all the facades facing four main directions (in separate scenarios) for all buildings from 0.4 (the albedo of conventional brick) to 0.7 (highly reflective brick). So, the East scenario has cool materials on its eastern facades. We modelled South, West and North scenarios like this. In the fifth perturbation scenario (scenario All), the albedo of all facades is 0.7 . By using the term cool façade (or a facade with cool materials) we mean the use of albedo 0.7 for a specific façade.

To implement the weather data for the simulations, ENVI-met 4.3 uses a component called ENVIwizard. Through different steps, date, time, initial meteorological conditions and further settings will be assigned. We used simple forcing method to enter hourly air temperature and relative humidity. Table 1 reports the most important conditions used in our simulations.

Net radiation values were calculated manually via equation 5 :

$R_{n}=H+L E+G$ 
We calculated net radiation $(R n)$ from the ENVI-met outputs of surface sensible heat flux $(H)$, latent heat flux (LE), and soil heat flux (G).

Table 1: Conditions used in the simulations with ENVI-met.

\begin{tabular}{|ll}
\hline Simulation day & $21^{\text {st }}$ of June \\
Simulation coordination & $33.9^{\circ} \mathrm{N}, 118.4^{\circ} \mathrm{W}$, Los Angeles, California, USA \\
Spatial resolution & $1 \mathrm{~m} \times 1 \mathrm{~m} \times 1 \mathrm{~m}(\mathrm{x}, \mathrm{y}, \mathrm{z})$ \\
Domain size $(\mathrm{x}, \mathrm{y}, \mathrm{z})$ & $100 \mathrm{~m} \times 100 \mathrm{~m} \times 40 \mathrm{~m}$ \\
Wind speed & $3.1 \mathrm{~m} / \mathrm{s}$ \\
Wind direction & $270^{\circ}($ West) \\
Relative humidity (in $2 \mathrm{~m})$ & $87 \%$ \\
Cloud coverage & $00^{\circ} \%$ \\
Indoor temperature & $293 \mathrm{~K}$ (clear sky) $\left.{ }^{\circ} \mathrm{C}\right)$ \\
Albedo & 0.2 (ground surface); 0.4 (walls); 0.7 (cool walls); 0.5 (roofs) \\
Heat capacity & $920 \mathrm{~J} / \mathrm{kgK}$ (ground surface); $650 \mathrm{~J} / \mathrm{kgK}$ (walls); $800 \mathrm{~J} / \mathrm{kgK}$ (roofs)
\end{tabular}

\subsection{Outdoor thermal comfort modelling}

To calculate the pedestrian's thermal comfort, we used RayMan Pro (Matzarakis et al., 2007, Matzarakis et al., 2010). This software calculates Physiological Equivalent Temperature (PET) (Höppe, 1999) via the following equation (Rohinton, 2016):

$P E T=1.2 T_{a}-2.2 v_{a}+0.55\left(T_{m r t}-T_{a}\right)$

where, PET is Physiological Equivalent Temperature $\left({ }^{\circ} \mathrm{C}\right) ; \mathrm{T}_{\mathrm{a}}$ is air temperature $\left({ }^{\circ} \mathrm{C}\right) ; \mathrm{T}_{\mathrm{mrt}}$ is mean radiant temperature $\left({ }^{\circ} \mathrm{C}\right)$; and $\mathrm{v}_{\mathrm{a}}$ is wind speed $(\mathrm{m} / \mathrm{s})$.

The unit of PET is degree Celsius, which makes it more tangible for thermal comfort assessment. RayMan calculates PET based on climatic and personal factors. Climatological factors (such as air temperature, and wind speed) are provided from the ENVI-met results. For the personal factors, we considered a 35 years old man, with $75 \mathrm{~kg}$ weight and $1.75 \mathrm{~m}$ height, standing in the neighbourhood (equivalent to $80 \mathrm{~W}$ of metabolism). For the clothing insulation, we considered 0.51 CLO for this person in a summer day in Los Angeles (0.51 CLO $=$ Men's briefs $0.04+$ shoes $0.02+$ socks $0.02+$ short sleeve dress shirt $0.19+$ trousers 0.24$)$. Changes in clothing or metabolism rate could impact the human thermal perception (PET). Detailed values of clothing and metabolism rates are accessible via ASHRAE 55 standard (2017).

It should be noted that $T_{\text {mrt }}$ and $T_{a}$ (which are the inputs of RayMan) are derived from ENVImet results. Table 2 summarises the research steps and associated references. 
Table 2: Summary of the research steps and corresponding references for each step.

\begin{tabular}{|l|l|l|}
\hline & Steps and analysis & References \\
\hline 1 & Retrieving weather data for simulations & (energyplus, 2018) \\
\hline 2 & $\begin{array}{l}\text { Insolation modelling via Chronolux plugin for Sketchup } \\
\text { Modelling and running ENVI-met scenarios }\end{array}$ & $\begin{array}{l}\text { (Bruse, 2020) } \\
\text { (Matzarakis et al., 2007, Matzarakis et } \\
\text { al., 2010) }\end{array}$ \\
\hline 4 & \begin{tabular}{l} 
Outdoor thermal comfort modelling \\
\hline
\end{tabular} & \\
\hline
\end{tabular}

\section{Results}

\subsection{Validation of the ENVI-met results}

Several studies have previously validated ENVI-met results with field measurements. Most of them have compared diurnal micrometeorological variables (such as air temperature) at pedestrian heights with measured or observed data (López-Cabeza et al., 2018, Acero and Arrizabalaga, 2018). In some studies, the validation was done through other CFD models (Perini et al., 2017) or grid sensitivity tests (Crank et al., 2018).

To evaluate the performance of the ENVI-met model in this research, we compared the hourly air temperature results from the Control model with the observed weather from Los Angeles airport. Data from receptor $\mathrm{C}$ at the centre of the Control model (previously shown in Figure 1 left) was used as the simulation data set. Figure 3-a shows the diurnal profile of air temperatures. The patterns of increasing and decreasing air temperatures (from sunrise to sunset) are fairly similar in both data sets, with the correlation coefficient of 0.96 . during the early morning and after sunset the deviations are minimum. Maximum deviation occurred during the hottest hour with $1.9^{\circ} \mathrm{C}$ at $14: 00$. As the graph shows, the software overestimates the air temperature during the day. This might be due to the fact that the whole ground surface of the simulation domain is covered with asphalt. Figure 3-b shows the scatter plot of the two data sets of air temperature. As the plot shows, higher deviations occur for higher air temperatures during the day. To have a better understanding of the deviations, root mean square deviation (RMSD) was calculated. The average hourly RMSD for the air temperature data sets was $1.4{ }^{\circ} \mathrm{C}$. This shows the average accuracy of the air temperature results from ENVI-met for discussing further results. 

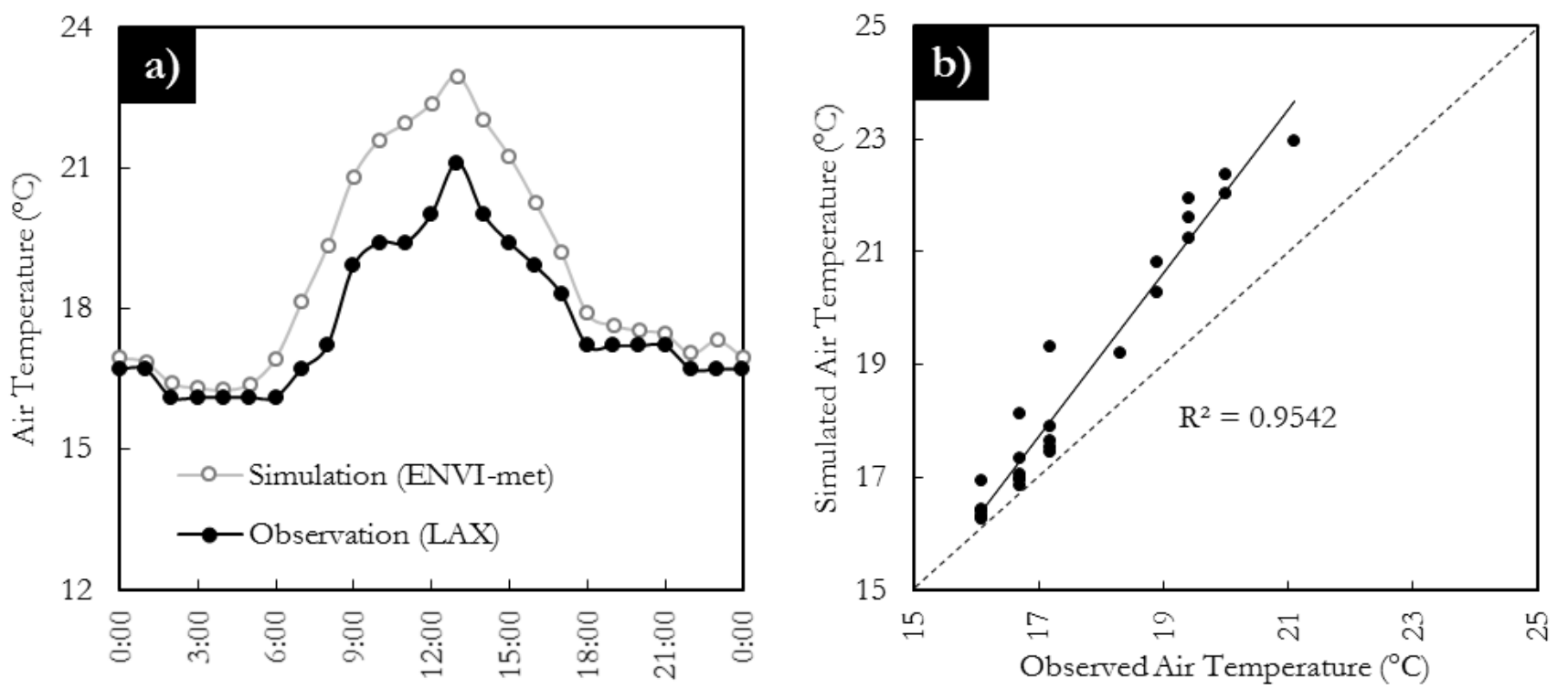

Figure 3: Comparison of simulated (from ENVI-met) and observed (from LAX weather station) air temperatures. Panel a) shows the diurnal profile of air temperatures. Panel b) presents the corresponding scatter plot.

\subsection{Insolation within the neighbourhood (the Control model)}

Insolation on different facades was calculated. Figure 4 illustrates the insolation on the southern façade as an example. As mentioned earlier, the simulated day is the $21^{\text {st }}$ of June. In Los Angeles, the sunrise is 4:47, and the sunset is 19:05 in this day (14 hours and 18 minutes in total). The calculated insolation for the facades from the highest to the lowest is: northern with $7 \mathrm{~h}: 34 \mathrm{~m}$, western and eastern with $7: 13 \mathrm{~m}$, and southern with $6 \mathrm{~h}: 39 \mathrm{~m}$ (see Appendix 1 for further details).

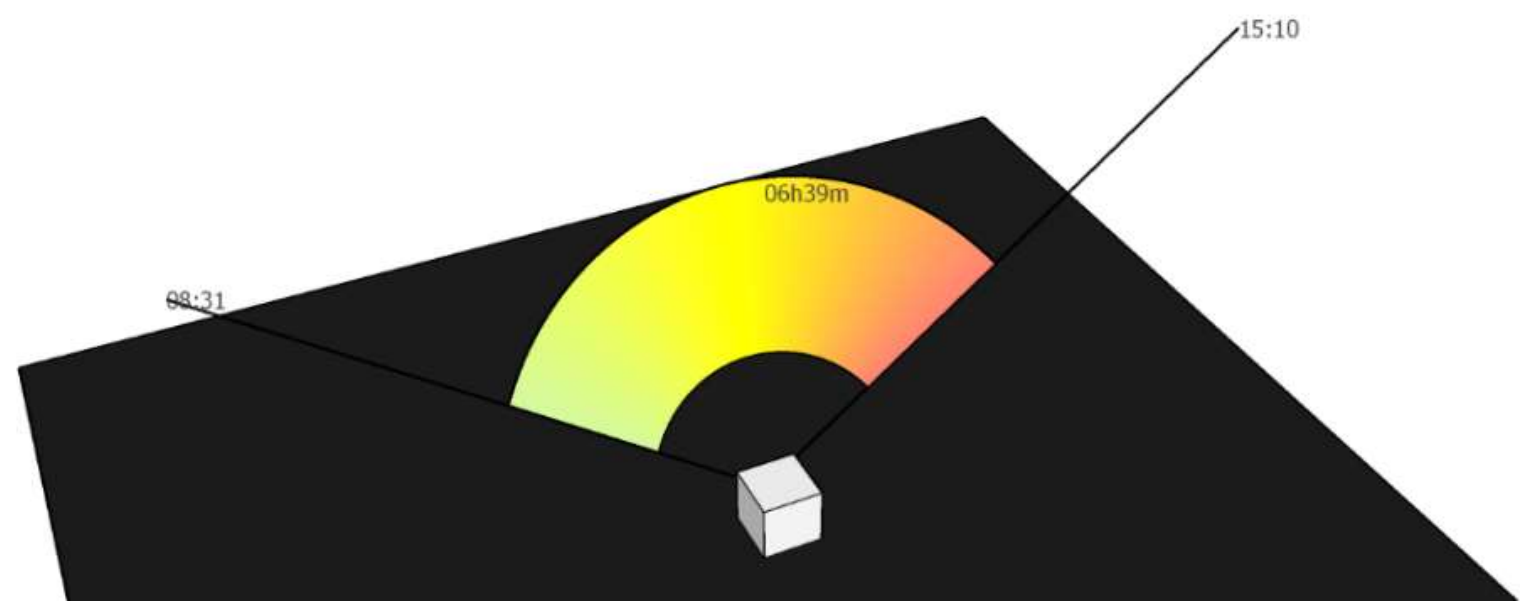

Figure 4: The insolation of southern façade for the coordinates of Los Angeles (CA) on the $21^{\text {st }}$ of June.

To study the amount of radiation within the neighbourhood canyons, mean radiant temperature ( $\left.T_{\mathrm{mrt}}\right)$ was calculated in four main receptors shown previously in Figure $1(\mathrm{~N}, \mathrm{E}$, 
$S$, and $\mathrm{W}$ points). The average $T_{\mathrm{mrt}}$ of $\mathrm{E}$ and $\mathrm{W}$ were considered as the $\mathrm{T}_{\mathrm{mrt}}$ of the $\mathrm{EW}$ canyon, and in a similar way for the NS canyon. Figure 5-a shows the diurnal mean radiant temperature within these canyons. After sunrise, $T_{\mathrm{mrt}}$ in the $\mathrm{EW}$ canyon increases very fast from 6:00. However, the NS canyon is shaded by the buildings at this time. $T_{\mathrm{mrt}}$ in the NS canyon starts to rise and reach the EW canyon from 9:00. $T_{\text {mrt }}$ is the same for the two canyons between 10:00 and 13:00, when the sun can radiate the two canyons similarly. There is a drop in $T_{\text {mrt }}$ for both canyons. This is due to the shading of the nearby buildings. After 13:00, the sun is rotating to the west, and then EW canyon still receives sun, while the NS canyon is obstructed. At 18:00, both canyons have the same $T_{m r t}$ as the sun altitude is very low, and the canyons are shaded. The average $T_{\text {mrt }}$ for the EW and NS canyons were 31.0 and $23.1^{\circ} \mathrm{C}$, respectively.

Figure 5 also illustrates the insolation within the EW and NS canyons. Figures 5-b and 5-c show the insolation on points $\mathrm{N}$ and $\mathrm{E}$ (respectively), which are previously marked in Figure 1. The EW canyon receives more than 10 hours of direct sun, while this is less than 4 hours for the NS canyon. This shows that the east and west facades receive sun in a longer period than north and south facades. 

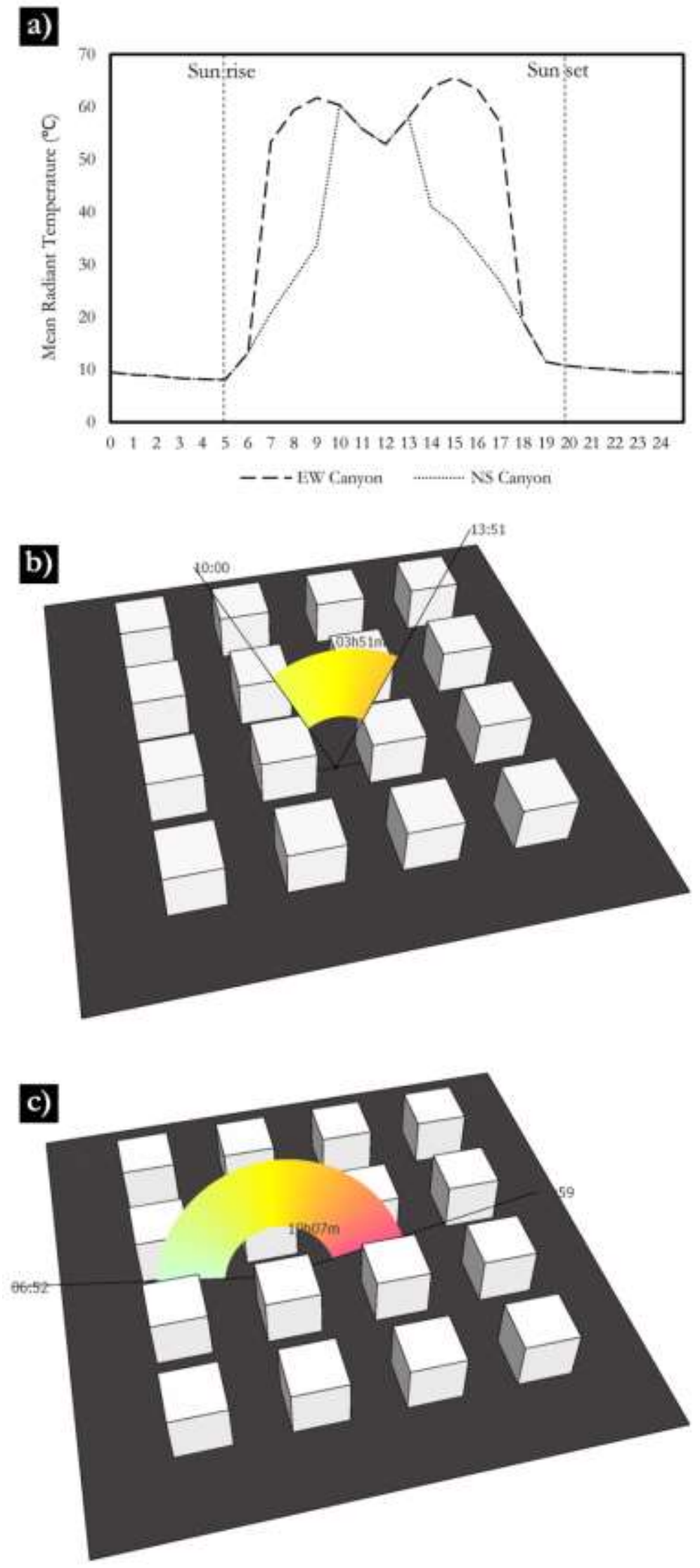

Figure 5: a) Diurnal profile of $T_{m r t}$ within the EW and NS canyons. b) The insolation within the NS canyon. c) The insolation within the EW canyon. 


\subsection{The impact of cooling different facades on the surface energy balance}

In this step of the study, the albedo of the facades was increased from 0.4 (conventional brick) to 0.7 (solar reflective brick). To study the impact of each scenario on the neighbourhood, energy balance and skin temperatures of the ground surface for each scenario were compared with the Control model.

Figure 6 illustrates the hourly profiles of surface energy balance within the neighbourhood (values are the averages for the whole neighbourhood ground surface cells). Figure 6a shows the net radiation differences. Net radiation $\left(R_{n}\right)$ was the same for all scenarios before sunrise. This was due to the nature of reflective facades that their performance is based on the availability of solar radiation. After sunrise, scenario All (with cool facades in all directions) reduced the net radiation more than the other scenarios. The maximum reduction was $10.4 \mathrm{~W} / \mathrm{m}^{2}$ at $14: 00$. The impact was reduced at 12:00 because the sun is radiating from maximum altitude (noon), and the roof receives more sun than the facades. The East and West scenarios perform similarly. This is in accordance with the time that they receive sun during that day. The maximum reductions for East and West scenarios are 6.8 and 7.1 $\mathrm{W} / \mathrm{m}^{2}$, respectively. The South scenario also reduces net radiation during the period that the south facades are radiated, with maximum $3.8 \mathrm{~W} / \mathrm{m}^{2}$. The north facades receive sun in the very early morning and evening with a very low altitude on this day. This makes two local maxima of reductions for the North scenario: first at 7:00 with $2.9 \mathrm{~W} / \mathrm{m}^{2}$, and second at 17:00 with $2.8 \mathrm{~W} / \mathrm{m}^{2}$.

Figure $6 \mathrm{~b}$ shows the reduction in sensible heat fluxes $(\mathrm{H})$ due to the reduction in net radiation in the five scenarios. Sensible heat flux is the conductive heat flux from different surfaces (facades, ground surface, etc.) to the atmosphere. The patterns of sensible heat flux reductions are similar to the net radiation reductions. All the scenarios reduced the sensible heat flux compared to the Control scenario during the sunlit hours. The reductions before sunrise and after sunset were zero. Maximum reduction occurred when all facades were improved (All scenario) with an average of $3.6 \mathrm{~W} / \mathrm{m}^{2}$. Average reduction for the East and West scenarios were similar $\left(1.2 \mathrm{~W} / \mathrm{m}^{2}\right)$. The least reduction occurred in the North scenario with average $0.9 \mathrm{~W} / \mathrm{m}^{2}$.

Figure $6 c$ illustrates the reductions in ground surface heat fluxes $(G)$ compared to the Control scenario. After sunrise, all the scenarios first reduced ground heat fluxes during the time they were exposed to the sun, and as soon as they were shaded, they started to increase the ground heat flux. This has been previously observed in other studies that showed high albedo surfaces could increase the ground heat flux because of their reflectivity instead of heat absorption.

Figure $6 d$ shows the surface temperature $\left(T_{s}\right)$ reductions for all scenarios compared to the Control scenario. Similar to the net radiation reductions, the All scenario reduced $T_{s}$ more than the other scenarios because of its more reflective facades compared to the others. Two maxima were observed at 10:00 and 15:00. The North scenario also had two maxima at 7:00 and 18:00 when the facades were receiving maximum radiation by the sun. Maximum reduction for the East scenario was at 9:00 with $0.2^{\circ} \mathrm{C}$. The same maximum reduction occurred for the West scenario at 15:00. 

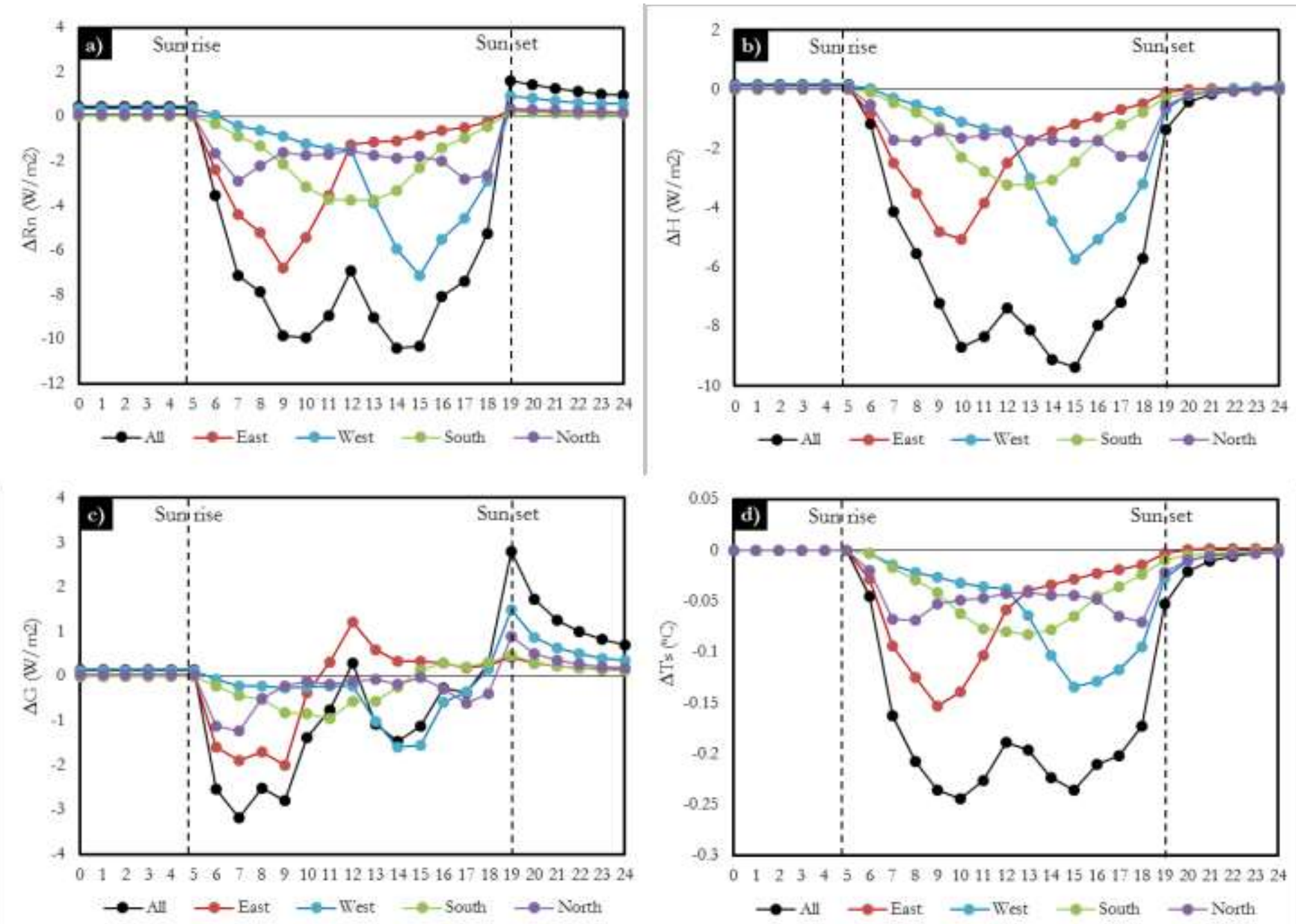

Figure 6: Hourly mean diurnal profiles of ground surface net radiation (a), sensible heat flux (b), ground heat flux (c), and surface temperature (d) in the perturbation scenarios compared to the Control scenario.

\subsection{The impact of cooling different facades on pedestrian thermal comfort}

All of the perturbation scenarios affected the microclimate, and consequently, they could change pedestrian thermal perception within the neighbourhood. We calculated Physiological Equivalent Temperature (PET) in five points (marked in Figure 1) in each scenario. We calculated the average hourly PET of the five points for each scenario, and then we compared them with the Control scenario.

Figure 7a shows the diurnal PET in the Control scenario (the average of five receptor points). PET classifications (Matzarakis et al., 1999) are also illustrated in the background (note that PET classes are theoretical, and they are not derived from a survey in the climate of Los Angeles (Potchter et al., 2018)). Between 8:00 and 16:00, PET is in Hot class, which means "strong heat stress" for a pedestrian. There is a very short period for a comfortable situation, in the very early morning, and the late afternoon. The hours before sunrise and sunset fall in the cool class.

Figure $7 \mathrm{~b}$ presents PET in the EW and NS canyons of the Control scenario. Note that the previous panel $(7 \mathrm{a})$ shows the average PET of all five points within the Control model. On 
average, PET in the NS canyon is $1.5^{\circ} \mathrm{C}$ lower than the EW canyon. The NS canyon is shaded during the day except between 10:00 and 14:00 (see Figure 5b). During this period, PET is increased to the Hot class immediately. Facades facing the NS canyon (east and west walls) can contribute to the thermal performance and thermal comfort of the canyon. The number of hours falling in the Hot class for the NS canyon is 5 (between 10:00 and 14:00), while this is 11 hours for the EW canyon (between 7:00 and 17:00).

In Figure 7-c we showed the reduction of PET in each scenario. We also highlighted the hot period from panel a) as "Strong Heat Stress" in the background. This was to place emphasis on the heat mitigation of each scenario during the critical period. Maximum reduction of PET occurred for the All scenario at $15: 00$ with $1.0^{\circ} \mathrm{C}$. Using cool facades in the east side led to $0.4{ }^{\circ} \mathrm{C}$ reduction in PET on average (between 8:00 and 16:00). Cool facades on south and west sides had the same average reduction of PET $\left(0.3^{\circ} \mathrm{C}\right)$. However, it should be noted that the maximum reduction for the West scenario was $0.7^{\circ} \mathrm{C}$ at $15: 00$, while maximum reduction for the South scenario was $0.4^{\circ} \mathrm{C}$ (between 11:00 and 13:00). North scenario showed the minimum reduction with $0.2^{\circ} \mathrm{C}$ during the heat stress period.

It is worth noting that both air temperature and mean radiant temperature affect PET (Taleghani, 2014). Some studies have shown that although high albedo materials reduce air temperature, they can increase radiation for pedestrians; thus, increasing PET (Erell et al., 2014). In the results presented here, small reductions of PET are observed. One main reason for that could be the abovementioned fact.
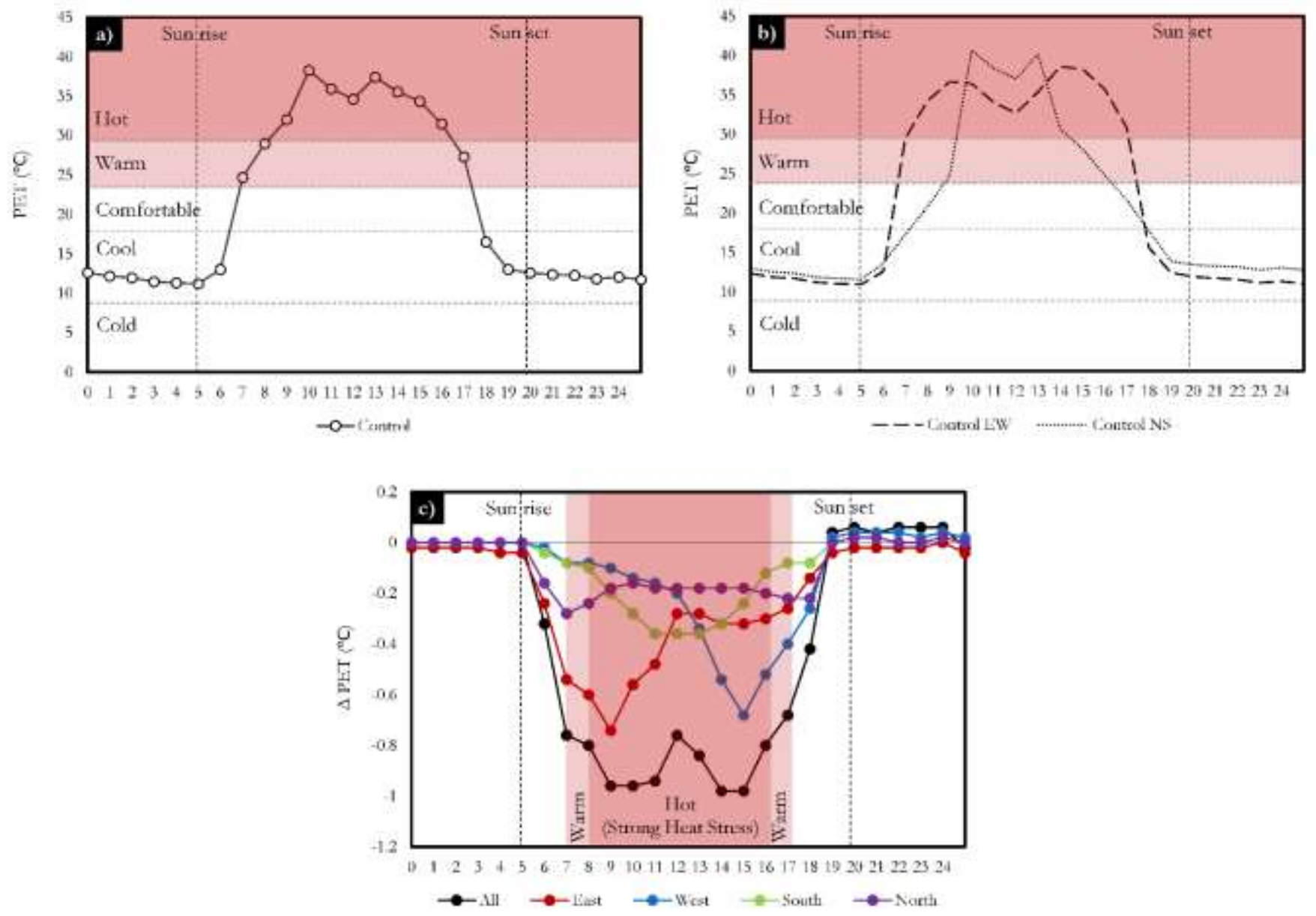

Figure 7: a) Diurnal profile of PET in the Control scenario (average of all receptors). b) Comparison of PET in the EW and NS canyon within the Control scenario. c) Comparison of PET in all scenarios with Control scenario. 


\subsection{The correlation of ground surface net radiation and pedestrian level PET}

Several studies have shown that among different factors, PET is mostly dependant on radiation in a microclimate (Thorsson et al., 2014, Kántor and Unger, 2011). Figure 8 shows the scatter plots illustrating the dependency of PET and net radiation in the scenarios. We highlighted the warm and hot classes of PET as "Moderate Heat Stress" and "Strong Heat Stress" in the plots.
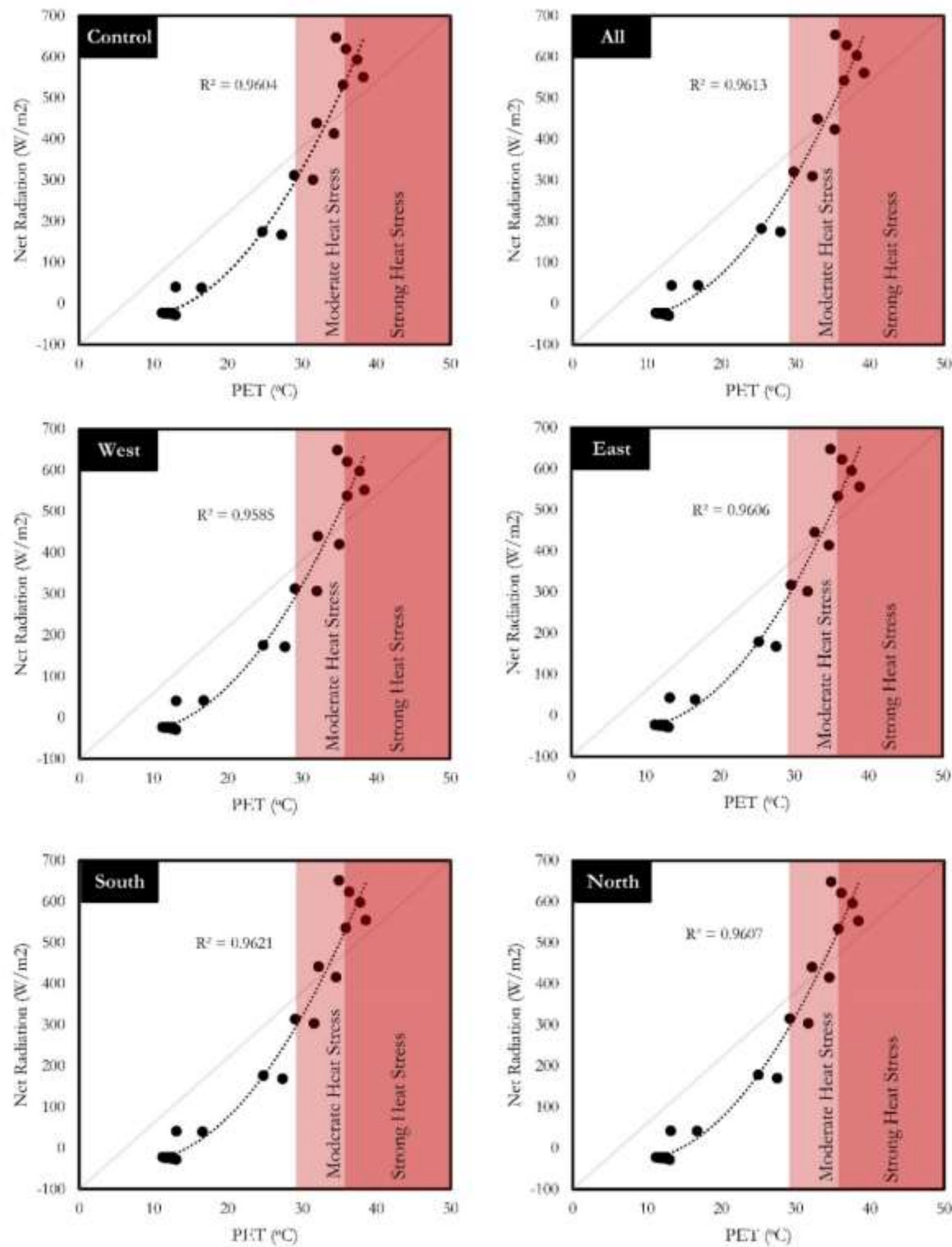

Figure 8: Scatter plots of PET and the ground surface net radiation within the scenarios. 
Different scenarios show that PET and net radiation are strongly correlated ( $94 \%$ on average in the six scenarios). These scenarios also showed that when net radiation exceeds 312 $\mathrm{W} / \mathrm{m}^{2}$ in the microclimate, PET crosses the comfortable range and falls in the warm (moderate heat stress) class. This makes the use of cool facades in their most effective orientation more important. In other words, by using cool facades in a proper way, net radiation could be reduced, and consequently the human thermal comfort could be improved. It should be noted that more research on cool facades are required to correlate net radiation and $\mathrm{PET}$ classes.

\section{Conclusions}

In this paper, we studied the impact of cooling different façade orientations on surface energy balance and human thermal comfort. Calculation of the insolation on different canyons showed that the EW canyon receives 6 hours of direct sun more than the NS canyon. In accordance with other studies on canyon orientations, we could show that the NS canyon is shaded most of the time. This makes the mean radiant temperature and PET lower in this canyon (compared to the EW canyon). In other words, this shows that EW canyons need more interventions than NS canyons.

Deploying the cool materials on four different facades showed that using cool materials on the east and west facades led to the maximum net radiation reductions. East facades with high albedo materials lower net radiation during the morning, and west facades do this during the late afternoon and early evening. Understanding this behaviour of the cool facades could be helpful when decision makers have a preferred time for cooling a microclimate. Regarding the impact of different facades on the human thermal comfort, we observed that cool facades in the east and west sides reduced PET more significantly compared to north and south.

In general, the paper showed that intervention on east and west facades makes more sense when our aim is to reduce heat in urban spaces. Understanding the differences between the façade orientations and their contribution to the energy balance of a microclimate can help cities and local authorities save money. This research showed that east and west facades play the most important role by receiving more sun (more insolation) compared to the other facades. Furthermore, architects and façade designers can use the findings of this paper to optimise indoor solar gains (and day lighting).

The research also showed that the east-west urban canyons receive (significantly) longer direct sun compared to the north-south canyons. Urban designers and planners can use this result while deploying heat mitigation strategies for a neighbourhood or a city. For instance, deploying green roofs or street trees within EW urban canyons will have much more cooling contribution to a neighbourhood or city compared to NS canyons. It should be noted that the scenarios in this paper were based on two main directions of urban canyons. We suggest that further research are needed to explore other orientations for each city/climate.

Furthermore, analysing urban surfaces' insolation in order to estimate their cooling potentials before investing on heat mitigation strategies such as reflective pavements are essential. Regarding future studies, different types of shading strategies (with vegetation or man-made screens that flexibly allow solar access in winter) could be studied in canyons with different directions. 


\section{Acknowledgment}

The authors would like to acknowledge Professor Andreas Matzarakis for providing them the RayMan Pro software. 


\section{References}

Acero, J. A. \& Arrizabalaga, J. 2018. Evaluating the performance of ENVI-met model in diurnal cycles for different meteorological conditions. Theoretical and Applied Climatology, 131, 455-469.

Ahmadi Venhari, A., Tenpierik, M. \& Taleghani, M. 2019. The role of sky view factor and urban street greenery in human thermal comfort and heat stress in a desert climate. Journal of Arid Environments, 166, 68-76.

Akbari, H. \& Kolokotsa, D. 2016. Three decades of urban heat islands and mitigation technologies research. Energy and Buildings, 133, 834-842.

Akbari, H. \& Matthews, H. D. 2012. Global cooling updates: Reflective roofs and pavements. Energy and Buildings, 55, 2-6.

Akbari, H., Ryan Bell, Tony Brazel, David Cole, Maury Estes, Gordon Heisler, David Hitchcock, Brenda Johnson, Megan Lewis, Greg Mcpherson, Tim Oke, Danny Parker, Alan Perrin, Joyce Rosenthal, David Sailor, Jason Samenow, Haider Taha, James Voogt, Darrell Winner, Kathy Wolf \& Zalph, B. 2008. Reducing Urban Heat Islands: Compendium of Strategies. United States Environmental Protection Agency.

Arnfield, A. J. 2003. Two decades of urban climate research: a review of turbulence, exchanges of energy and water, and the urban heat island. International Journal of Climatology, 23, 1-26.

Ashrae 2017. ASHRAE Standard 55-2017. ASHRAE 55- Thermal Environmental Conditions for Human Occupancy. Atlanta, GA: ASHRAE

Baniassadi, A., Sailor, D. J., Crank, P. J. \& Ban-Weiss, G. A. 2018. Direct and indirect effects of highalbedo roofs on energy consumption and thermal comfort of residential buildings. Energy and Buildings, 178, 71-83.

Bruse, M. 2004. ENVI-met 3.0: Updated Model Overview. Accessed 02.10.2018 http://www.envimet.net/documents/papers/overview30.pdf.

Bruse, M. 2019. Turbulence Model in ENVI-met [Online]. Available: http://www.botworld.info/doku.php?id=kb:turbulence [Accessed].

Bruse, M. 2020. ENVI-met website [Online]. Available: http://www.envi-met.com [Accessed].

Bruse, M. \& Fleer, H. 1998. Simulating surface-plant-air interactions inside urban environments with a three dimensional numerical model. Environmental Modelling \& Software, 13, 373-384.

Crank, P. J., Sailor, D. J., Ban-Weiss, G. \& Taleghani, M. 2018. Evaluating the ENVI-met microscale model for suitability in analysis of targeted urban heat mitigation strategies. Urban Climate, 26, 188-197.

Energyplus. 2018. EnergyPlus Weather Data [Online]. U.S. Department of Energy. Available: https://energyplus.net/weatherlocation/north_and_central_america_wmo_region_4/USA/CA/USA_CA_Los.Angeles.IntI.AP. 722950_TMY3 [Accessed 01.02.2018].

Epa 2008. Reducing Urban Heat Islands: Compendium of Strategies. United States Environmental Protection Agency.

Erell, E., Pearlmutter, D., Boneh, D. \& Kutiel, P. B. 2014. Effect of high-albedo materials on pedestrian heat stress in urban street canyons. Urban Climate, 10, 367-386.

Erell, E., Pearlmutter, D. \& Williamson, T. J. 2012. Urban Microclimate: Designing the Spaces Between Buildings, Earthscan.

Höppe, P. 1999. The physiological equivalent temperature - A universal index for the biometeorological assessment of the thermal environment. International Journal of Biometeorology, 43, 71-75.

Kántor, N. \& Unger, J. 2011. The most problematic variable in the course of humanbiometeorological comfort assessment - the mean radiant temperature. Central European Journal of Geosciences, 3, 90-100. 
Kottek, M., Grieser, J., Beck, C., Rudolf, B. \& Rubel, F. 2006. World Map of the Köppen-Geiger climate classification updated. Meteorologische Zeitschrift, 15.

Levinson, R. 2019. Using solar availability factors to adjust cool-wall energy savings for shading and reflection by neighboring buildings. Solar Energy, 180, 717-734.

López-Cabeza, V. P., Galán-Marín, C., Rivera-Gómez, C. \& Roa-Fernández, J. 2018. Courtyard microclimate ENVI-met outputs deviation from the experimental data. Building and Environment, 144, 129-141.

Matzarakis, A., Mayer, H. \& Iziomon, M. G. 1999. Applications of a universal thermal index: physiological equivalent temperature. International Journal of Biometeorology, 43, 76-84.

Matzarakis, A., Rutz, F. \& Mayer, H. 2007. Modelling radiation fluxes in simple and complex environments-application of the RayMan model. International Journal of Biometeorology, 51, 323-334.

Matzarakis, A., Rutz, F. \& Mayer, H. 2010. Modelling radiation fluxes in simple and complex environments: basics of the RayMan model. Int J Biometeorol, 54, 131-9.

Mohegh, A., Rosado, P., Jin, L., Millstein, D., Levinson, R. \& Ban-Weiss, G. 2017. Modeling the climate impacts of deploying solar reflective cool pavements in California cities. Journal of Geophysical Research: Atmospheres, 122, 6798-6817.

Oke, T. R., Mills, G., Christen, A. \& Voogt, J. A. 2017. Urban Climates, Cambridge, Cambridge University Press.

Perini, K., Chokhachian, A., Dong, S. \& Auer, T. 2017. Modeling and simulating urban outdoor comfort: Coupling ENVI-Met and TRNSYS by grasshopper. Energy and Buildings, 152, 373384.

Potchter, O., Cohen, P., Lin, T.-P. \& Matzarakis, A. 2018. Outdoor human thermal perception in various climates: A comprehensive review of approaches, methods and quantification. Science of The Total Environment, 631-632, 390-406.

Rohinton, E. 2016. Urban Climate Challenges In The Tropics: Rethinking Planning And Design Opportunities, World Scientific Publishing Company.

Sailor, D. J., Baniassadi, A., O'lenick, C. R. \& Wilhelmi, O. V. 2019. The growing threat of heat disasters. Environmental Research Letters, 14, 054006.

Santamouris, M. 2014. Cooling the cities - A review of reflective and green roof mitigation technologies to fight heat island and improve comfort in urban environments. Solar Energy, 103, 682-703.

Santamouris, M. 2015. Regulating the damaged thermostat of the cities-Status, impacts and mitigation challenges. Energy and Buildings, 91, 43-56.

Santamouris, M., Gaitani, N., Spanou, A., Saliari, M., Giannopoulou, K., Vasilakopoulou, K. \& Kardomateas, T. 2012. Using cool paving materials to improve microclimate of urban areas Design realization and results of the flisvos project. Building and Environment, 53, 128-136.

Santamouris, M., Haddad, S., Saliari, M., Vasilakopoulou, K., Synnefa, A., Paolini, R., Ulpiani, G., Garshasbi, S. \& Fiorito, F. 2018. On the energy impact of urban heat island in Sydney: Climate and energy potential of mitigation technologies. Energy and Buildings, 166, 154-164.

Taha, H. 2008. Meso-urban meteorological and photochemical modeling of heat island mitigation. Atmospheric Environment, 42, 8795-8809.

Taha, H. 2013. The potential for air-temperature impact from large-scale deployment of solar photovoltaic arrays in urban areas. Solar Energy, 91, 358-367.

Taha, H. 2015. Meteorological, air-quality, and emission-equivalence impacts of urban heat island control in California. Sustainable Cities and Society, 19, 207-221.

Taha, H. 2017. Characterization of Urban Heat and Exacerbation: Development of a Heat Island Index for California. Climate, 5, 59.

Taleghani, M. 2014. Dwelling on Courtyards: Exploring the energy efficiency and comfort potential of courtyards for dwellings in the Netherlands. PhD, Delft University of Technology. 
Taleghani, M., Crank, P. J., Mohegh, A., Sailor, D. J. \& Ban-Weiss, G. A. 2019a. The impact of heat mitigation strategies on the energy balance of a neighborhood in Los Angeles. Solar Energy, 177, 604-611.

Taleghani, M., Marshall, A., Fitton, R. \& Swan, W. 2019b. Renaturing a microclimate: The impact of greening a neighbourhood on indoor thermal comfort during a heatwave in Manchester, UK. Solar Energy, 182, 245-255.

Thorsson, S., Rocklöv, J., Konarska, J., Lindberg, F., Holmer, B., Dousset, B. \& Rayner, D. 2014. Mean radiant temperature - A predictor of heat related mortality. Urban Climate, 10, Part 2, 332345.

Zhang, J., Mohegh, A., Li, Y., Levinson, R. \& Ban-Weiss, G. 2018. Systematic Comparison of the Influence of Cool Wall versus Cool Roof Adoption on Urban Climate in the Los Angeles Basin. Environmental Science \& Technology, 52, 11188-11197. 


\section{Appendix 1:}

Table 3: Insolation on different facades.

\begin{tabular}{|l|l|l|}
\hline Façade & Period(s) & Total insolation \\
\hline North & $04: 47$ to $07: 57 \& 14: 41-19: 05$ & $7 \mathrm{~h} 34 \mathrm{~m}$ \\
\hline West & $11: 52$ to $19: 05$ & $7 \mathrm{~h} 13 \mathrm{~m}$ \\
\hline East & $04: 39$ to $11: 52$ & $7 \mathrm{~h} 13 \mathrm{~m}$ \\
\hline South & $8: 31$ to $15: 10$ & $6 \mathrm{~h} 39 \mathrm{~m}$ \\
\hline
\end{tabular}

